\title{
A field study on the impacts of implementing concepts and elements of industry 4.0 in the biopharmaceutical sector
}

\author{
Felipe Silva $^{1}$, David Resende ${ }^{2}$, Marlene Amorim ${ }^{1}$, Monique Borges ${ }^{3}$ \\ ${ }^{1}$ GOVCOPP/DEGEIT, University of Aveiro, Portugal ${ }^{2}$ GOVCOPP/ESTGA, University of \\ Aveiro, Portugal, ${ }^{3}$ GOVCOPP, University of Aveiro, Portugal.
}

\begin{abstract}
This article proposes a field study on the applications and impacts of Industry 4.0 (I4.0) in the biopharmaceutical sector, based on an initial literature review. The world is facing a new industrial revolution that is happening at a faster pace than the previous ones. The central idea is the integration between the virtual and the real world through elements that will allow a greater degree of automation and digitization of processes The fieldwork, carried out between July and December 2019, considered semi-structured interviews with managers of pharmaceutical companies or specialists in the I4.0 theme. The interviews pointed out the need for the biopharmaceutical sector to adapt to the concepts of 14.0 and identified its main benefits and barriers. The perceptions were considerably diversified, with the benefits in operational efficiency, productivity and quality being the most scored items. Regarding the main barriers, the most highlighted by the interviewees were the need to break organizational cultural standards, regulatory requirements, the lack of organizational strategies for implementation and the lack of qualified professionals. In conclusion, this work in progress is a contribution to the biopharmaceutical sector and reinforces the imminent need for companies to adapt to this new reality.
\end{abstract}

Keywords: Industry 4.0; Pharma 4.0; Biopharma 4.0; Bio 4.0. 


\section{Introduction}

The terms "advanced manufacturing", "digitization" or "industry 4.0" (I4.0) have been widely cited in the general literature and are directly related to the future of manufacturing and maintaining industrial competitiveness. The world is facing a new industrial revolution that is happening at a faster pace than the previous ones. The central idea is the fusion or integration between the virtual and the real world trough elements that will allow a greater degree of automation and digitization of processes (Figure 1). The term I4.0 originated from a project integrated with the high-tech strategy of the German government, and aimed at the automation and digitization of the manufacturing industry (Daudt \& Willcox, 2016).

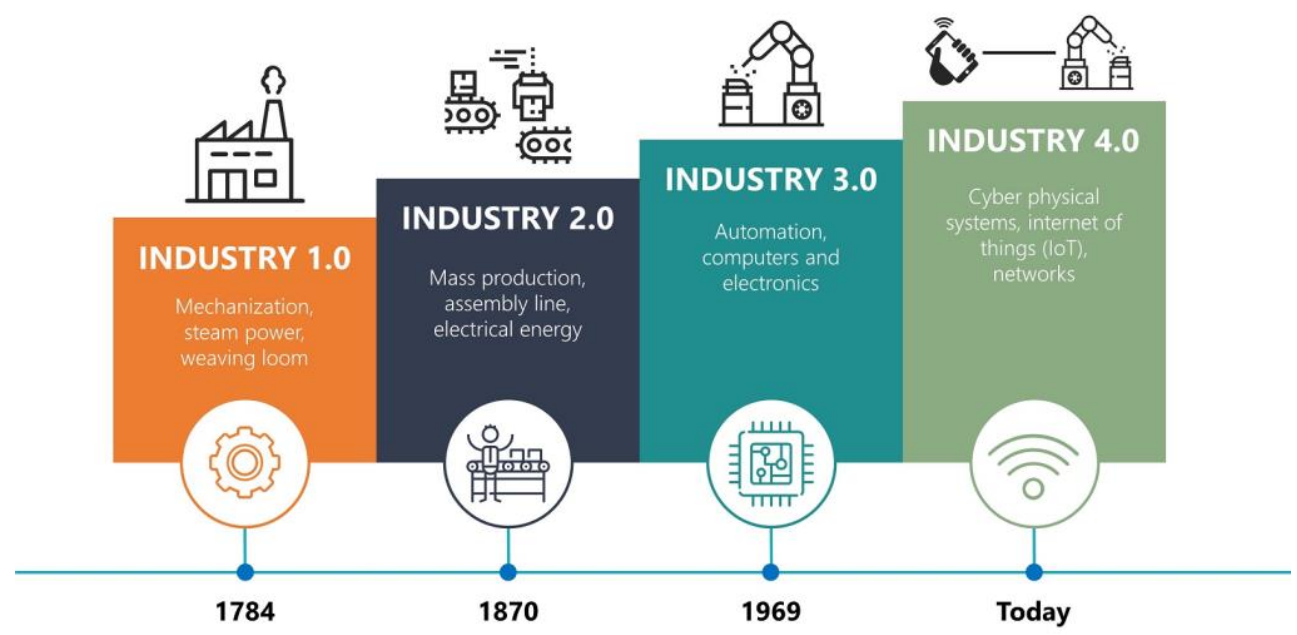

Fig. 1. Industry 4.0 - Fourth Industrial Revolution (Great Myanmar Institute, 2016).

As the concepts of I4.0 are still at an early stage, any attempt to classify their elements becomes complex. However, there is consensus about fundamental elements that underlie the notion ofI4.0, CPS (Cyber-Physical Systems) and the IoT (Internet of Things). The technologies that allow the applicability of I4.0, defined as structuring elements, include automation, Machine to Machine Communication (M2M), Artificial intelligence (AI), BigData analytics, cloud computing, systems integration and cybersecurity. Finally, the complementary elements are those that are not mandatory, but increase the possibilities of application of I4.0, which include 3D printing, RFID tag, QR code, augmented reality and virtual reality, among others (Sacomano \& Sátyro, 2018). 


\subsection{The Biopharmaceutical Industry 4.0}

Currently, investments in technological innovation are increasingly migrating from pharmochemical chemicals to biological ones (large molecules produced in living cells). The technological platforms for their production involve the use of living, attenuated or inactivated organisms, whole or in subunits, genetically modified or not, for the production of vaccines or biopharmaceuticals. They require an extraordinary technological challenge, involving expensive and sophisticated activities that include cell culture processes, high performance purification systems, quality control with highly sensitive methodologies, among others (Silva \& Caulliraux, 2016).

\section{Methodology}

The methodology proposed for this study includes the interview of professionals who work in managerial positions in biopharmaceutical industries or I4.0 specialists. In this context, 10 semi-structured interviews were carried out with professionals from different countries between August 2019 and January 2020. The objective was to collect information and perceptions about I4.0 in the biopharmaceutical sector and the expected impacts.

All respondents and the institutions in which they operate had their identities preserved for reasons of industrial secrecy. The interviews were conducted using the semi-structured method, where there is a confluence of previously prepared questions (related to trends, impacts and mapping of the phenomenon studied around the world) with others generated from the responses of the interviewees. The information collected was analyzed by qualitative analysis methods, such as content and narrative analysis.

\section{Results}

Most respondents perceive a strong need for biopharmaceutical companies to adapt, by implementing the elements the elements of I4.0 in their operations, especially at the risk of losing competitiveness. Some respondents believe in a moderate trend due to industry characteristics and peculiarities that include severe regulatory requirements and risks to people's safety. Factors like these can slow I4.0 applications in the industry. 
The impacts of implementing concepts and elements of industry 4.0 in the biopharmaceutical sector

Table 1. Interviewees in the Field - Biopharmaceutical Sector Managers and Experts at I4.0

\begin{tabular}{|c|c|c|c|}
\hline Interviewed & $\begin{array}{c}\text { Company } \\
\text { Characteristics }\end{array}$ & Company Position & Interviewed Category \\
\hline A & $\begin{array}{l}\text { Portugal Private } \\
\text { Pharmaceutical }\end{array}$ & $\begin{array}{c}\text { Industrial Director - } \\
\text { Portugal }\end{array}$ & $\begin{array}{c}\text { Biopharmaceutical } \\
\text { Manager }\end{array}$ \\
\hline B & $\begin{array}{l}\text { Portugal Private } \\
\text { Pharmaceutical }\end{array}$ & $\begin{array}{c}\text { Digital Transformation } \\
\text { Project Manager - } \\
\text { Portugal }\end{array}$ & $\begin{array}{c}\text { Biopharmaceutical } \\
\text { Manager }\end{array}$ \\
\hline $\mathrm{C}$ & $\begin{array}{c}\text { Transnational Private } \\
\text { Bioharmaceutical }\end{array}$ & $\begin{array}{l}\text { Academic Management } \\
\text { Program Manager - Spain }\end{array}$ & $\begin{array}{c}\text { Biopharmaceutical } \\
\text { Manager }\end{array}$ \\
\hline $\mathrm{D}$ & $\begin{array}{l}\text { Brazilian Private } \\
\text { Bioharmaceutical }\end{array}$ & $\begin{array}{c}\text { Production Director - } \\
\text { Brazil }\end{array}$ & $\begin{array}{c}\text { Biopharmaceutical } \\
\text { Manager }\end{array}$ \\
\hline $\mathrm{E}$ & $\begin{array}{l}\text { Transnational Private } \\
\text { Bioharmaceutical }\end{array}$ & IT Manager - Brazil & $\begin{array}{c}\text { Biopharmaceutical } \\
\text { Manager }\end{array}$ \\
\hline $\mathrm{F}$ & $\begin{array}{l}\text { Digital Transformation } \\
\text { in Production Lines }\end{array}$ & $\begin{array}{c}\text { Digital Latin America - } \\
\text { Brazil }\end{array}$ & $\begin{array}{c}\text { Biopharmaceutical } \\
\text { Manager }\end{array}$ \\
\hline G & $\begin{array}{l}\text { Artificial Intelligence } \\
\text { (AI) Consulting and I4.0 }\end{array}$ & $\begin{array}{c}\text { Head of Machine } \\
\text { Learning and Innovation } \\
\text { R\&D - EUA }\end{array}$ & I4.0 Specilist \\
\hline $\mathrm{H}$ & $\begin{array}{l}\text { Digital Transformation } \\
\text { in Production Lines }\end{array}$ & $\begin{array}{l}\text { Director (CEO) - } \\
\quad \text { Portugal }\end{array}$ & I4.0 Specilist \\
\hline I & $\begin{array}{c}\text { Academy } \\
\text { Public University - } \\
\text { Coimbra }\end{array}$ & $\begin{array}{c}\text { Full Professor of } \\
\text { Robotics - Portugal }\end{array}$ & I4.0 Specilist \\
\hline $\mathrm{J}$ & $\begin{array}{l}\text { Private Microconductor } \\
\text { Company I4.0 - Portugal }\end{array}$ & $\begin{array}{c}\text { Company Owner and } \\
\text { Director - Portugal }\end{array}$ & I4.0 Specilist \\
\hline
\end{tabular}

While explaining individual perceptions a diverse set of aspects come to debate. The efficiency gain in operations was the most scored amongst respondents, from the perspective of reducing waste, reducing operating costs and increasing productivity. These benefits are supported by the prospects of real-time quality controls, more detailed process data collection and analysis or predictive equipment maintenance. Quality-related gains, production customization, and reduced time to launch new products were also frequently scored (Figure 3). The literature describes that the adoption of new I4.0-based technologies is expected to improve biopharmaceutical companies towards establishing more robust, flexible and faster manufacturing processes, reducing unplanned outages, fewer equipment defects, better 
deadlines, and more agile quality management, analysis and decision making (Markarian, 2018). In addition to the expectation of greater productivity, the interviewees reinforced that real-time monitoring allows the identification of characteristics that make it impossible, for example, to continue a batch, avoiding waste of working hours, energy consumption and raw materials.

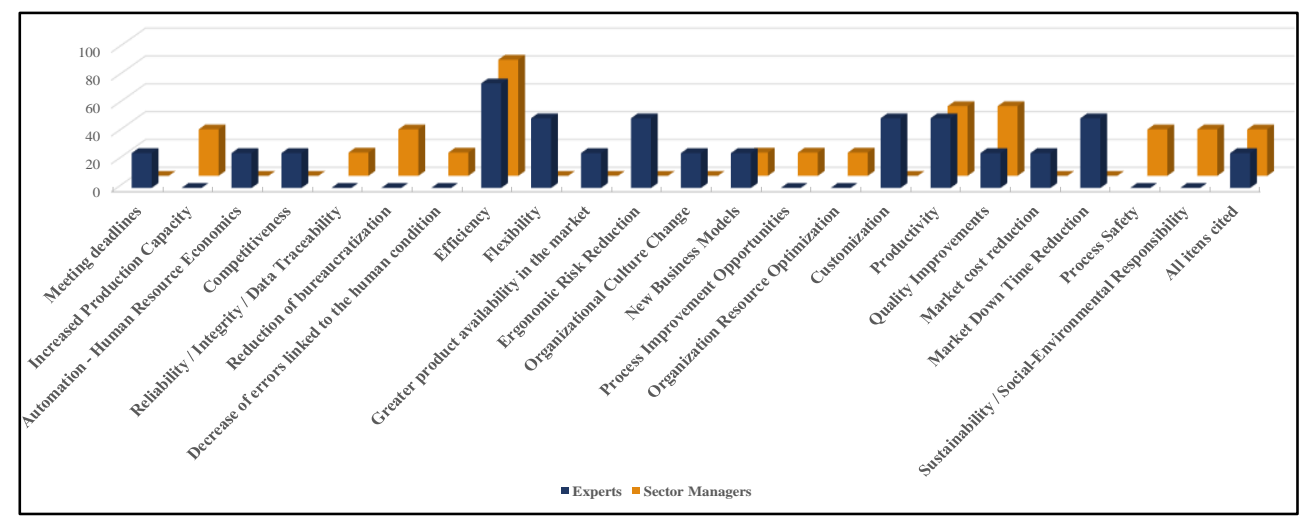

Figure 2. Main benefits identified by respondents of 14.0 in the production of biomedicines.

As described in literature, products obtained in living systems are usually unstable and unpredictable (Silva \& Caulliraux, 2016). Therefore, intense and rigorous monitoring in real time is essential. This minimizes the possibility of unwanted products and consequently increases productivity. In a cell fermentation or propagation process, for example, the more closely monitored the reaction medium containing living cells, the greater the possibility of obtaining the desired products. Compared to conventional strategy, the higher level of control and monitoring (based on complex algorithms) will allow analysis and predictive actions to avoid process or equipment failures (Romero-Torres et al., 2018). In this sector equipment is generally aseptic and often subjected to aggressive cleaning agents. Therefore, many of them have significantly high episodes of malfunctions. It is important to detect this predictively so that actions can be taken in advance. Most respondents, especially managers working in the sector, scored this benefit.

Interesting also in this sector is the possibility of increasingly automated production processes, with machines interacting directly with other machines (M2M) without human intervention. In aseptic processes, the presence of any particles (man is the main source) can lead to episodes of batch contamination and damage to millionaires. In the era of I4.0, products are equipped with identifiers, such as QR bar codes or RFID tags, which after being read by the equipment are able to guide the correct sequence of operations through them (Sacomano \& Sátyro, 2018) Some respondents antecipate gains in quality and efficiency with the reduction of failures linked to the human condition. 
Intelligent processes are expected to be increasingly useful in the biopharmaceutical field. A temperature or $\mathrm{pH}$ sensor positioned at a specific point in a bioprocess, for example, can not only transmit the collected values to a computer or cellular exchange, but also compare them to programmed default values and, if necessary, output signals to actuators correct temperature or $\mathrm{pH}$ without any human intervention (Sacomano \& Sátyro, 2018). The possibility of using intelligent aseptic robots can also be highly interesting in overly repetitive processes or involving physical, chemical or biological hazards (Keller et al., 2018). As reported in the interviews, there is the prospect of extraordinary gains in mitigating ergonomic risks, efficiency, productivity, among others.

Respondents also frequently cited benefits related to digitization and paper replacement. The sensors collect process data and forward it to servers or computers in the cloud for storage and tracking. Punctuated benefits such as socio-environmental responsibility, reliability of data storage under GMP conditions, reduction of bureaucracy and quality are directly related to the theme. The direct connection between CPS, IoT, Big Data, AI and cloud computing will allow the analysis and crossing of this data in a more precise and profound way, resulting in several other benefits mentioned (efficiency, productivity, optimization of resources, among others). Research shows that approximately $70 \%$ of the data collected today in the biopharmaceutical industry is unused (Manzano \& Langer, 2018).

The possibility of more personalized medicines produced on more flexible production lines was also punctuated in the field interviews. This is an interesting perspective because it is common for certain biomedicines (therapeutic proteins, for example) to serve a small and targeted number of patients. Elements in I4.0 are expected to be able to offer leaner production processes that compensate for production on smaller scales and offer affordable market costs. Factories designed in modular structures, for example, allow greater flexibility and customization in the manufacture of products (Hammer, 2018). The range of single use systems or equipment is another recent challenge in the biopharmaceutical industry. A bioreactor, for example, requires significant manual efforts to connect all the necessary parts to the process. A system can be configured to require the operator to register the barcode on each disposable part to ensure proper component assembly and registration (Markarian, 2018). Virtual or augmented reality tools can also help in this regard, avoiding errors, waste and increasing the security of the process. All of these benefits were raised by the interviewees. Another point cited by the interviewees, especially the experts, is the expectation that more products will be made available to consumers more quickly. Among other elements of I4.0 used for this purpose (Big Data, 3D Printing etc.), modern virtual simulators, for example, quickly manufacture and evaluate products under development, without the need for physical occupation of the factory.

Regarding the main barriers and risks, opinions were quite varied. Reference goes to aspects commonly discussed in the literature, as the difficulty in breaking organizational patterns and 
cultures, the stringent regulatory requirements of the biopharmaceutical sector, the lack of definition of strategic alignment for the implementation of the I4.0 elements, high investment and lack of qualified professionals. The interviewees also stressed that it is no use for companies to invest heavily in technological elements of I4.0 if they do not consider strongly the aspects mentioned.

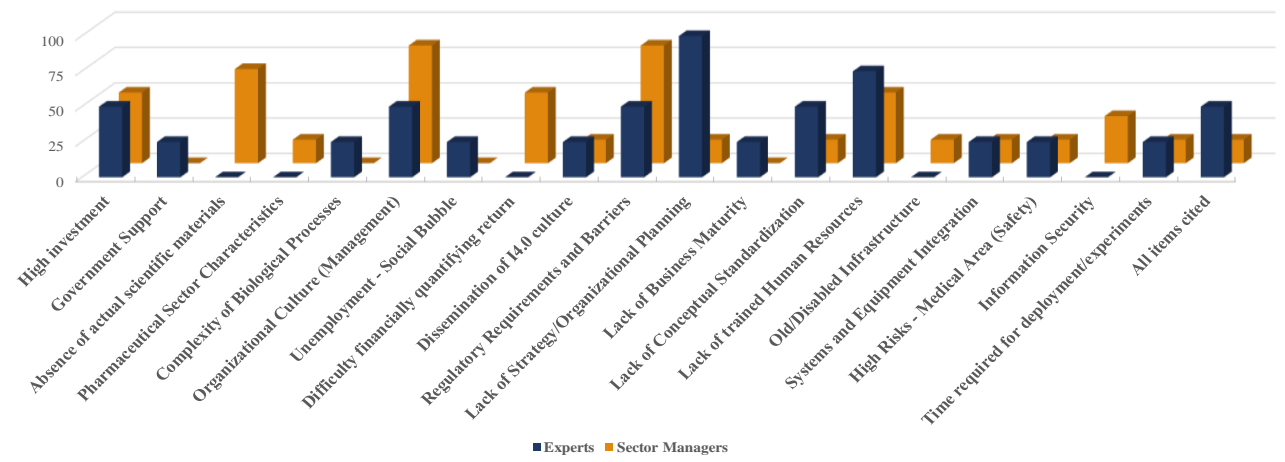

Figure 3. Main barriers identified by respondents in the adoption of I4.0 in the production of biomedicines.

Factors such as low or old IT infrastructure, poor dissemination of I4.0 culture in society (customers, suppliers, regulatory agencies, etc.), lack of business maturity and difficulties in system integration were also cited. The integration between the different systems is extremely challenging point to I4.0. Efforts to standardize the systems are being made among manufacturers to reduce this problem (Romero-Torres et al., 2018). The fragility of information security systems was also addressed in the interviews. It is good practice to separate business data from GMP (Good Manufacturing Practice) production data using a kind of "industrial segregated zone" (Markarian, 2018). Keeping security levels current with the amount of data as a result of increasing connectivity between systems, equipment, and processes that communicate through IoT is highly challenging. The "social bubble" caused by automation and consequent unemployment was also pointed out as a growing concern.

Some studies have been helpful in comparing I4.0's slower pace of insertion into the biopharmaceutical industry than in other areas, such as a Silicon Valley semiconductor company (Romero-Torres et al., 2017). As corroborated by the interviewees, this can be justified by some sector peculiarities. In addition to the regulatory issues inherent in products directly related to life, there is the complexity of biotechnology processes (reported especially by biopharmaceutical managers) and the absence of concrete cases in the literature (little exchange of experience). About the last, most of the documents were found in electronic journals specialized in the biopharmaceutical sector and not in the traditional scientific bases. Probably this fact stems from the scientific incipience of the subject. 


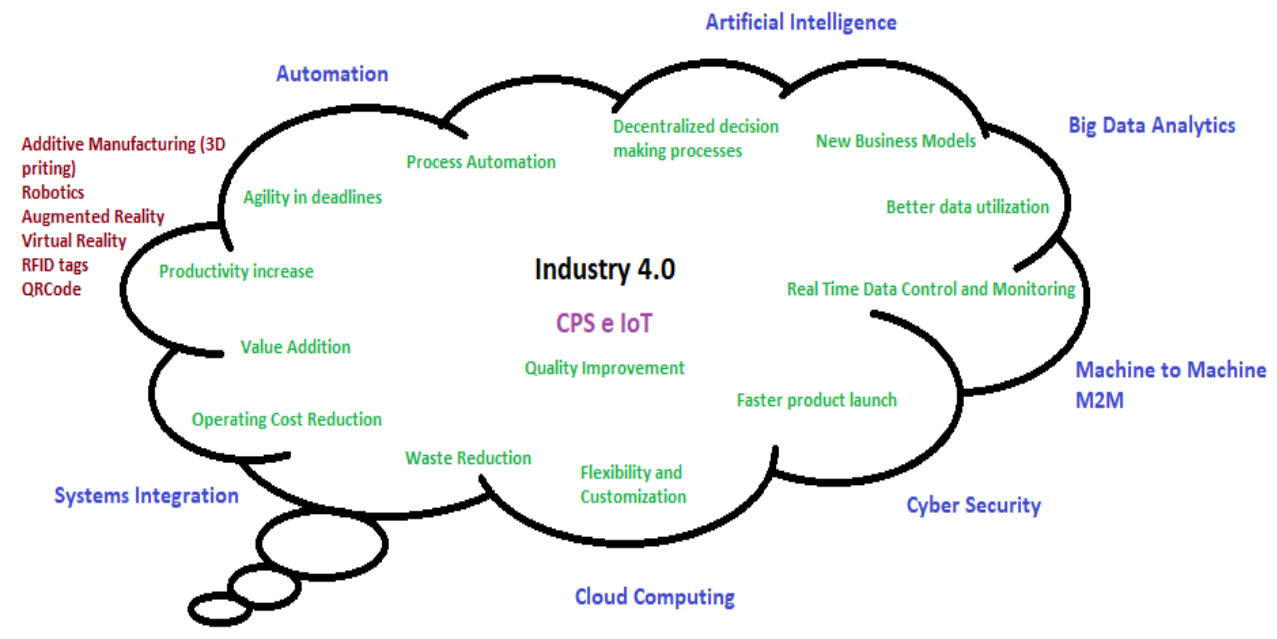

Figure 4. The main technological elements of I4.0.

The figure above summarizes the technological elements of I4.0 and some of the main benefits mentioned in the field interview. In the perception of the interviewees in general, it is essential that companies carefully align the organization's strategies and needs with the available technological elements. It is of utmost importance to carry out a prior assessment on the conditions of integration between systems, equipment and technologies.

\section{Conclusion}

Overall, field interviews reinforce not only the trend, but the need for biopharmaceutical companies to move into the I4.0 era, especially at the risk of losing competitiveness. The field results, quite diversified, confirmed the main impacts reported in the literature, in addition to bringing others. As for the benefits, efficiency was the main point raised, followed by gains in quality and increased productivity. Gains related to personalization, reduced ergonomic risks and reduced time to market were also scored. Regarding the main barriers, questions were raised that even contribute to a slower pace of implementation of I4.0 than in other sectors. Strict regulatory aspects, the need to break organizational cultures, the lack of qualified professionals, the lack of strategic alignment for implementation and high investment were frequently scored. Others, such as, the high complexity of biological processes and the threat of a "social bubble" due to the reduction in job availability caused by process automation were also addressed. The low number of scientific articles focused on the area still shows incipience and presents the opportunity for new publications, in addition to encouraging organizations to move into the I4.0 era. It is essential to deepen the exchange of experience and knowledge between producers (the entire logistics chain), regulatory 
agents and society itself. As a limitation of the study, we can consider the low number of respondents and the consequent impossibility of statistical treatment to provide more consistent conclusions. The expectation is that a new study will be carried out with a more in-depth systematic review, the participation of more respondents and the identification of case by area companies that have already gone through the digitization process.

\section{References}

Daudt, G., \& Willcox, L. (2016). Reflexões críticas a partir das experiências dos Estados Unidos e da Alemanha em manufatura avançada. In BNDES Setorial (44th ed., pp. 5-46). Rio de Janeiro.

Great Myanmar Institute. (2016). Revoluções e o Mundo. Retrieved January 22, 2020, from http://www.greatmyanmarinstitute.com/revolution/

Keller, M., Baum, G., Schweizer, M., Bürger, F., Gommel, U., \& Bauernhansl, T. (2018). Optimized Robot Systems for Future Aseptic Personalized Mass Production. Procedia CIRP, 72, 303-309. https://doi.org/10.1016/j.procir.2018.03.066

Manzano, T., \& Langer, G. (2018). Getting ready for pharma 4.0 - Data integrity in cloud and big data applications. International Society for Pharmaceutical Engineering (ISPE), 72-19. https://doi.org/10.1177/030857599602000113

Markarian, J. (2018). Industry 4.0 in Biopharmaceutical Manufacturing - Modern technologies offer opportunities to increase manufacturing efficiency. BioPharm International, 31(7), 36-38. $\quad$ Retrieved from http://www.biopharminternational.com/industry-40-biopharmaceutical-manufacturing-0

Romero-Torres, S., Moyne, J., \& Kidambi, M. (2017). Towards pharma 4.0; Leveraging lessons and innovation from Silicon valley. American Pharmaceutical Review, 7(1).

Romero-Torres, S., Wolfram, K., Armando, J., Ahmed, S., Ren, J., Shi, C., ... Guenard, R. (2018). Biopharmaceutical Process Model Evolution- Enabling Process Knowledge Continuum from an Advanced Process Control Perspective. American Pharmaceutical Review. Retrieved from https://www.americanpharmaceuticalreview.com/FeaturedArticles/352447-Biopharmaceutical-Process-Model-Evolution-Enabling-ProcessKnowledge-Continuum-from-an-Advanced-Process-Control-Perspective/

Sacomano, J., \& Sátyro, W. (2018). Indústria 4.0: conceitos e elementos formadores. In Edgard Blucher Ltda. (Ed.), Indústria 4.0: conceitos e fundamentos (pp. 27-47). São Paulo.

Silva, F., \& Caulliraux, H. (2016). A Desverticalização no Setor de Produção de Biomedicamentos e a Utilização das Empresas CMOs (Contract Manufacturing Organization). Produto \& Produção, 17(4), 1-18. 